\title{
AN INSTRUMENT INSPECTION CLAMP
}

\section{To the Editorial Committee of the British Journal of Ophthalmology}

DEAR Sirs-I was glad to find in Mr. B. W. Rycroft's article “ An Instrument Inspection Clamp" (B.J.O., 1953, 37, 508) support for the thesis that optical control of sharp instruments is superior to the trial-drum.

This idea, first introduced to the ophthalmic world by Schmidt (1911), has been a commonplace in the manufacture of razor-blades for a generation, and was first reduced (I believe) to a practical clinical level by J. F. Kayser and myself $(1946,1949)$.

The attachment of instruments to a slit-lamp head-rest for inspection by the slit lamp has already been described by my one-time Registrar (now in Johannesburg) Dr. S. Etzine (1949), who found a carpenter's clamp costing $1 s .4 d$. quite adequate.

One might with great respect make two comments about the use of the slit lamp for this purpose by nursing staff:

(1) the magnification of most slit lamps is on the low side, as a magnification of about $\times 40$ is needed for the adequate assessment of trephines and $\times 90$ for knives, though even $\times 20$ might still be superior to the trial-drum;

(2) unless the theatre sister is more permanent than most, the surgeon would probably find it quicker and better to do the work himself than to teach the method to her and successors.

The extra care our instruments require is a strong argument in favour of male theatre staff as being less liable to leave on marriage.

45, Park SQuare, Leeds, 1.

Yours faithfully, JOHN Foster.

August 31, 1953.

\section{REFERENCES}

Etzine, S. (1949). S. Afr. med. J., 23, 1044.

FOSTER, J. (1949). Trans. Inst. Brit. surg. Tech., 6, 47.

KAYSer, J. F., and Foster, J. (1946). Proc. roy. Soc. Med., 39, 835.

SCHMIDT, H. (1911). Z. Augenheilk., 25, 154.

\section{BOOK REVIEW}

Le Mécanisme de la Vision des Couleurs (Mechanism of Colour Vision). BY J. SÉGAL. 1953. Pp. 351, 120 figs, 1 col. plate, 130 refs. Doin, Paris. (3,000 Fr.; 63s.).

A new theory-whether right or wrong-is refreshing, especially in regard to a subject such as the mechanism of colour vision. As research work continues on this vast and complex subject the tendency has been to apply an unending series of modifications to the existing theories as each has been found incapable of accounting for new facts. Ségal, working in Henri Piéron's Laboratory for the Physiology of Sensation in Paris, has advanced for the first time a new, systematic theory which must excite interest and will certainly not easily be accepted. In this readable monograph he reviews existing hypotheses and finds them all wanting. He accepts the weight of evidence in favour of three fundamental types of chromatic receptors: that for extreme red he places in the crystalline pigment of the pigmentary epithelium of the retina, that for green in the retinal cones, and that for blue-violet in the macular pigment. The elaboration of this theory to explain the physiology of colour vision and the facts of colour blindness form the basis of this monograph which is at once interesting, stimulating, and provocative. Certainly the author has succeeded in enthusiastically throwing aside the mass of ideas and interpretations which make up our " scientific baggage" on this subject, and in making a completely fresh start. 